\title{
BÉO PHÌ VÀ NHIỄM COVID-19 NẬNG
}

Nguyễn Thị Nhạn

Trường Đại học Y Dược Huế

DOI: 10.47122/vjde.2020.41.2

\begin{abstract}
Obesity and risk of severe COVID-19

Obesity represents a higher risk of COVID-19 infection, which can be characterized clinically from mild to fatal. The severe acute respiratory syndrome coronavirus 2 (SARS-CoV-2) is the virus responsible and may lead to the requirement of a mechanical ventilation in intensive care units and premature death. The underlying medical conditions in obese patientssuch as cardiovascular, pulmonary disease, diabetes, hypertension or obstructive sleep apnea syndrome. Otherwise, there are an inadequate and excessive immunological responses, "cytokine storm", aggravated by ectopic intrathoracic fat depots. These findings require reinforced preventive and curative measures among obese patients to limit the risk of progression towards an unfavorable outcome in case of COVID-19.
\end{abstract}

Key words: Obesity, severe acute respiratory syndrome coronavirus 2 (SARSCoV-2)

\section{TÓM TẮT}

Béo phì có nguy cơ cao nhiễm COVID-19, với đặc trưng lâm sàng từ mức độ nhẹ đến tử vong. Hội chứng hô hấp cấp tính nặng do Coronavirus 2 (SARS-CoV-2) là do virus gây ra và có thể dẫn đến yêu cầu thở máy tại các đơn vị chăm sóc đặc biệt và tử vong sớm.

Các tình trạng bệnh lý cần quan tâm ở bệnh nhânbéo phì như bệnh tim mạch, bệnh phổi, đái tháo đường, tăng huyết áp hoặc hội chứng ngưng thở khi ngủ do tắc nghẽn. Nếu không, sẽ có những đáp ứng miễn dịch không đầy đủ và quá mức, "cơn bão cytokine", trầm trọng hơn bởi các kho chất béo "lạc cỗ" trong lồng ngực. Những phát hiện này đòi hỏi các biện pháp phòng ngừa và điều trị tăng cường ở những bệnh nhân béo phì bị nhiễm COVID-
19, để hạn chế nguy cơ tiến triển thành dự hậu không tốt.

Từ khóa: béo phì, Hội chứng hô hấp cấp tính nặng do Coronavirus 2

Chịu trách nhiệm chính: Nguyễn Thị Nhạn

Ngày nhận bài: 7/8/2020

Ngày phản biện khoa học: 8/9/2020

Ngày duyệt bài: 11/10/2020

Email: bsnhan2003@yahoo.com

Điện thoại: 0989635735

\section{1. ĐẠTT VẤN Đî̀}

Béo phì thường làm gia tăng độ trầm trọng của nhiễm COVID-19, đe dọa chăm sóc tăng cường, hổ trợ hô hấp và nguy cơ tử vong cao.

Trong số bn nhập viện ở một bang của Mỹ, phần lớn $(68,5 \%)$ cần phải thông khí hổ trợ, trong đó $33 \%$ có BMI giữa $30-40 \mathrm{~kg} / \mathrm{m}^{2}$ và $7,3 \%$ có $\mathrm{BMI}>40 \mathrm{~kg} / \mathrm{m}^{2}$. Trong một $\mathrm{NC}$ trên 1317 bệnh nhân đái tháo đường nhiễm COVID-19 nhập viện tại Pháp, phân tích đa biến cho thấy BMI là yếu tố nguy cơ độc lập của tiêu chí đầu tiên chỉ định đặt nội khí quản trong thông khí cơ học và tử vong trong vòng 7 ngày kể từ khi nhập viện [1].

Có nhiều lý do: tổn thương cơ chế thông khí, có bệnh phối hợp như đái tháo đường hay hội chứng ngưng thở do nghẽn lúc ngủ, kể cả tăng khối mỡ ngoài lồng ngực càng hạn chế hô hấp; sau cùng là phản ứng miê̂n dịch và viêm không thích hợp, tăng tiết các cytokine gây viêm, gây "bão cytokine”. Điều này càng ảnh hưởng nặng trên suy kiệt hô hấp cấp, do vậy có những phương cách dự phòng và điều trị ở bệnh nhân béo phì để hạn chế tiến triển bất lợi khi nhiễm COVID-19

\section{DICH TỄ}

Béo phì có thể làm rối loạn đáp ứng miễn dịch, nên dễ bị nhiễm vi trùng cũng như virus ìnfluenza, nguy cơ này gia tăng và dễ nhiễm bệnh kéo dài hơn so người không béo phì, 
nhưng không rõ nhiều đối với nhiễm COVID19, tuy nhiên thời gian cách ly (14 ngày) có thể kéo dài hơn ở người béo phì có nhiễm COVIS-19.

Một nghiên cứu đã công bố tại New York trên 5700 bệnh nhân nhập viện vì COVID-19, có $42 \%$ bệnh nhân có $B M I>30 \mathrm{~kg} / \mathrm{m}^{2}$ và $19,0 \%$ BMI $>35 \mathrm{~kg} / \mathrm{m}^{2}[11]$.

Nghiên cứu tại Ý cho thấy có sự liên quan giữa béo phì và COVID-19 rõ ràng ở nhóm trẻ tuổi so với toàn quần thể thì không rõ. Nghiên cứu sơ khởi tại 63 trung tâm Hồi sức tại Pháp gồm 769 bệnh nhân, hơn $40 \%$ có BMI $\geq 30 \mathrm{~kg} / \mathrm{m}^{2}$. NC gộp ở Lille (Pháp), trong số bn nhập viện HSCC do bệnh phổi năng vì COVID-19, có $47 \%$ bn có BMI $\geq 30 \mathrm{~kg} / \mathrm{m}^{2}$, nhóm béo phì nặng với $\mathrm{BMI} \geq 35 \mathrm{~kg} / \mathrm{m}^{2}$ tăng nguy cơ đặt nội khí quản một cách có ý nghĩa, không phụ thuộc vào tuổi, tăng $\mathrm{HA}$ và đái tháo đường.

Tỉ lệ $\mathrm{BN}$ béo phì nhập viện tại Mỹ khác nhau tùy vùng miền, $21 \%$ có $\mathrm{BMI}$ từ $30-34$ $\mathrm{kg} / \mathrm{m}^{2}$ và $16 \%$ có $\mathrm{BMI} \geq 35 \mathrm{~kg} / \mathrm{m}^{2}$. Những người dưới 60 tuổi, thì nguy cơ nhập viện hoặc cần hổ trợ thông khí tăng gấp 1,8 lần nếu có $\mathrm{BMI}$ từ 30 - 34, và tăng 3,6 lần nếu $\mathrm{BMI} \geq 35 \mathrm{~kg} / \mathrm{m}^{2}$.

\section{CƠ CHẾ}

Nguy cơ gia tăng ở bn béo phì bị nhiễm COVID-19 nặng là do nhiều cơ chế:

- Rối loạn thông khí: Phản ứng miễn dịch và gia tăng viêm; tất cả do vai trò của vị trí dự trữ mỡ hoặc các bệnh phối hơp với béo phì, ảnh hưởng xấu đến bệnh [14], [13].

Nguy cơ liên quan đến cơ chế thông khí: Khi bị béo phì đặc biệt là thể nặng, thường có tổn thương thông khí, do giảm sức cơ hô hấp, giảm thể tích hiệu quả phổi, tăng đề kháng đường thông khí và cuối cùng giảm trao đổi khí tốt. Khi bệnh nhân béo phì bị nhiễm COVID-19 với tổn thương phổi trầm trọng sẽ kéo theo giảm oxy máu, và làm trầm trọng thêm bối cảnh lâm sàng, và cần thiết phải thông khí cơ học[1].

- Nguy cơ có bệnh kèm: Béo phì thường phối hợp với nhiều bệnh suất khác nhau và tăng nguy cơ COVID-19 trầm trọng. Đó là đái tháo đường, tăng huyết áp, hội chứng ngưng thở khi ngủ do nghẽn, tổn thương thận, gan nhiễm mỡ.

Ngoài ra béo phì dễ bị nghẽn tắt tĩnh mạch và tăng nguy cơ tắt mạch phổi, biến chứng thường gặp ở bệnh nhiễm COVID-19 và có khả năng gia tăng tử suất.

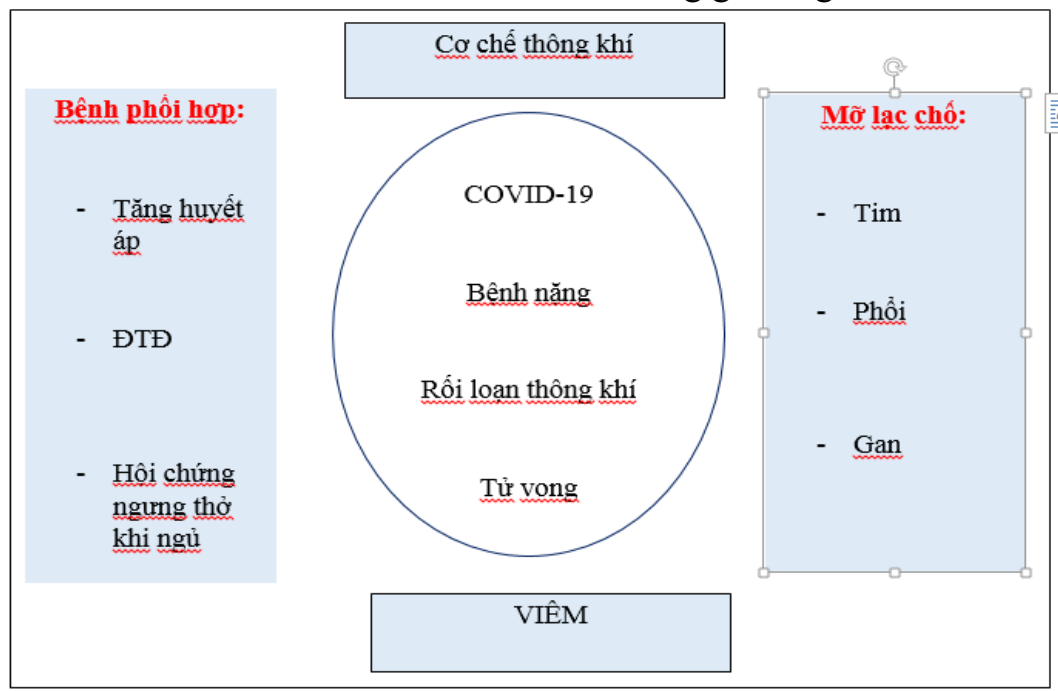

Hình 1. Cơ chế liên quan giữa mức độ trầm trọng của COVID-19 và béo phì [1]

- Gia tăng phản ứng viêm: Ở BN béo phì có gia tăng khối mỡ, tăng nguy cơ rối loạn chuyển hóa do tăng mỡ bụng, tích tụ mỡ quanh tạng, và tăng yếu tố tiền viêm từ mô mỡ tiết ra. Có sự tương tác giữa mô mỡ và hệ thống miễn dịch, cũng như rối loạn chuyển hóa và viêm. 
Phản ứng viêm càng tăng nếu béo phì kèm đái tháo đường týp 2 . Mô mỡ ở $\mathrm{BN}$ béo phì là nơi dự trữ và dễ phát tán coronavirus, hoạt hóa hệ thống miễn dịch và khuyếch đại phản ứng liên quan đến cytokines [12].

- Virus lan tỏa trong mô mõ và hoạt hóa theo con đường tăng viêm và tăng tiết cytokine. Angiotensin converting enzyme 2 receptor biểu hiệu trên nhiều loại tế bào, bao gồm tế bào mỡ, tế bào cơ trơn và tế bào nội mạc mạch máu, là cửa đi vào của $\mathrm{SARS}-\mathrm{CoV}$ 2 , nên làm tổn thương nhiều cơ quan và mạch máu.Ngoài ra nhiều tế bào mô mỡ là nơi cư trú của nhiều virus gồm $\mathrm{H} 1 \mathrm{~N} 1$, type $\mathrm{A}$ influenza và adenovirus 36 , cytomegalovirus, tế bào nội mạc mạch máu [SARS-CoV-2, đại thực bào (influenza $\mathrm{A}, \mathrm{SARS}-\mathrm{CoV}$, adenovirus36, virus gây thiếu hụt miễn dịch ở người) và lymphocytes (SARS-CoV).

Mặc dù SARS-CoV-2 đã được phân lập chỉ với mức thấp trong máu, chúng ta không thể loại trừ coronavirus lan truyền từ máu vào mô mỡ với sự kết gắn rất cao tại các thụ thể trên tế bào mỡ cơ thể (mõ̃ tạng, mỡ trong ngực, mỡ bọc ở tim, quanh thận, mỡ mạc treo ruột). Virus có khả năng hoạt động kéo dài trong cơ quan, hoạt hóa hệ thống miễn dịch "tiền-hoạt" và theo con đường tín hiệu cytokine, và người béo phì có rối loạn đại thực bào và tế bào lympho, tăng đáp ứng miễn dịch sai lạc, gây tổn thương mô lan rộng do kich thích của Coronavirus.

Tường trình gần đây của Wuhan gợi ý rằng SARS-CoV-2 gây rối loạn đáp ứng điều hòa miễn dịch ở những bệnh nhân nhiễm nặng COVID-19 [6], đặc trưng bằng sự giảm số lượng tế bào Lympho $\mathrm{T}$ lưu hành, cũng như giảm tỉ subtype Lympho $\mathrm{T}$ helper/Lympho Tsuppressor ở người béo phì, nhất là tác động của SARS-CoV-2 trên chức năng tế bào $\mathrm{T}$.

Các yếu tố cytokine gây viêm đặc hiệu nhu TNF- $\alpha$ (Tumor necrosis factor, interleukin (IL)-1, và IL-6 có trong mô mõ người béo phì [16], và khi nhiễm, COVID-19 sẽ khuyếch đại đáp ứng cytokine trong mô mỡ. Bão cytokine được thấy rõ trong nhiều trường hợp nhiễm COVID-19 đường hô hấp, được biểu lộ bởi nhiều loại cytokine khác nhau như interferon, IL, chemokine, TNF, và đáp ứng yếu tố kích thích đơn dòng.

Đáp ứng viêm ở phổi phản ảnh sự mất cân bằng giữa cytokine tiền viêm (như $\mathrm{TNF}$ và IL-1 $\beta$, IL-10 được sản xuất bởi macrophage và Lymphocyte $\mathrm{T}$ ( $\mathrm{T}$ helper 2 and regulatory $\mathrm{T}$ cells) hoạt động điều hòa âm của viêm;trong khi đó IL-6 và thụ thể hòa tan của nó làm tăng hoạt tính của IL-6 trên tế bào đích. IL-6 là yếu tố dự báo độc lập về tử suất cao. Mô mỡ ở người là nguồn chính của IL-6 và thụ thể $\mathrm{IL}-6$, và do vậy mô mỡ có thể là nguồn cung cấp tín hiệu hoạt hóa IL-6 từng đợt khi nhiễm virus (Hình 2).

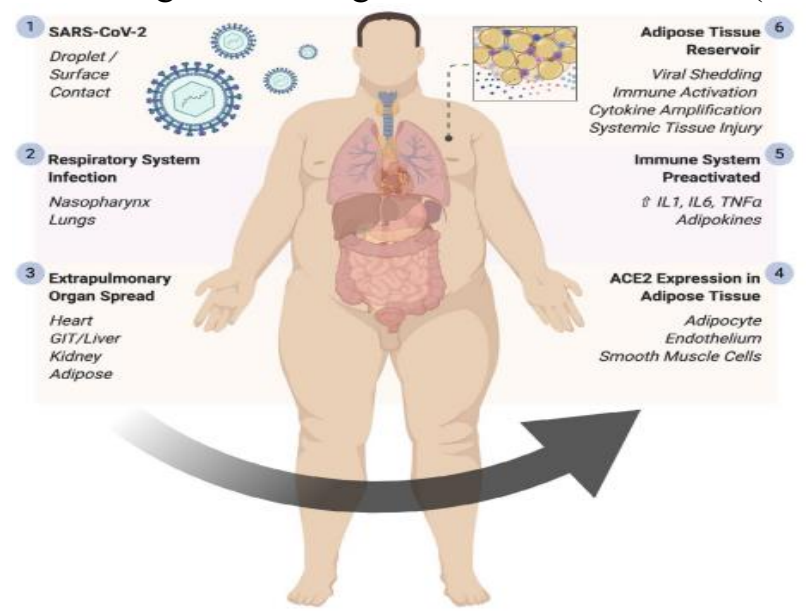

Hình 2. Mô mỡ là nơi dự trữ SARS-CoV-2 xâm nhập, virus lan tỏa, hoạt hóa miễn dịch, và khuyếch đại cytokine. GIT (gastrointestinal tract; IL, interleukin); SARS-CoV-2 (severe acute respiratory syndrome coronavirus 2); TNF (tumor necrosis factor)[1] 
- Kho chứa lạc chỗ của mõ̃. Béo phì đặc trưng bởi các kho chứa lạc chổ của mỡ, không chỉ ở quanh tạng trong bụng, mà còn có trong các cơ quan: gan, cơ vân, nhất là cơ tim, trong lồng ngực, trung thất, mô mỡ quanh tim.Các kho lạc chổ này cũng liên quan đến sự phóng thích cytokine gây viêm như IL-6. Giả thuyết cho rằng còn có cả các tiểu kho chứa lipid trong phổi và các khoảng kẻ phế bào.

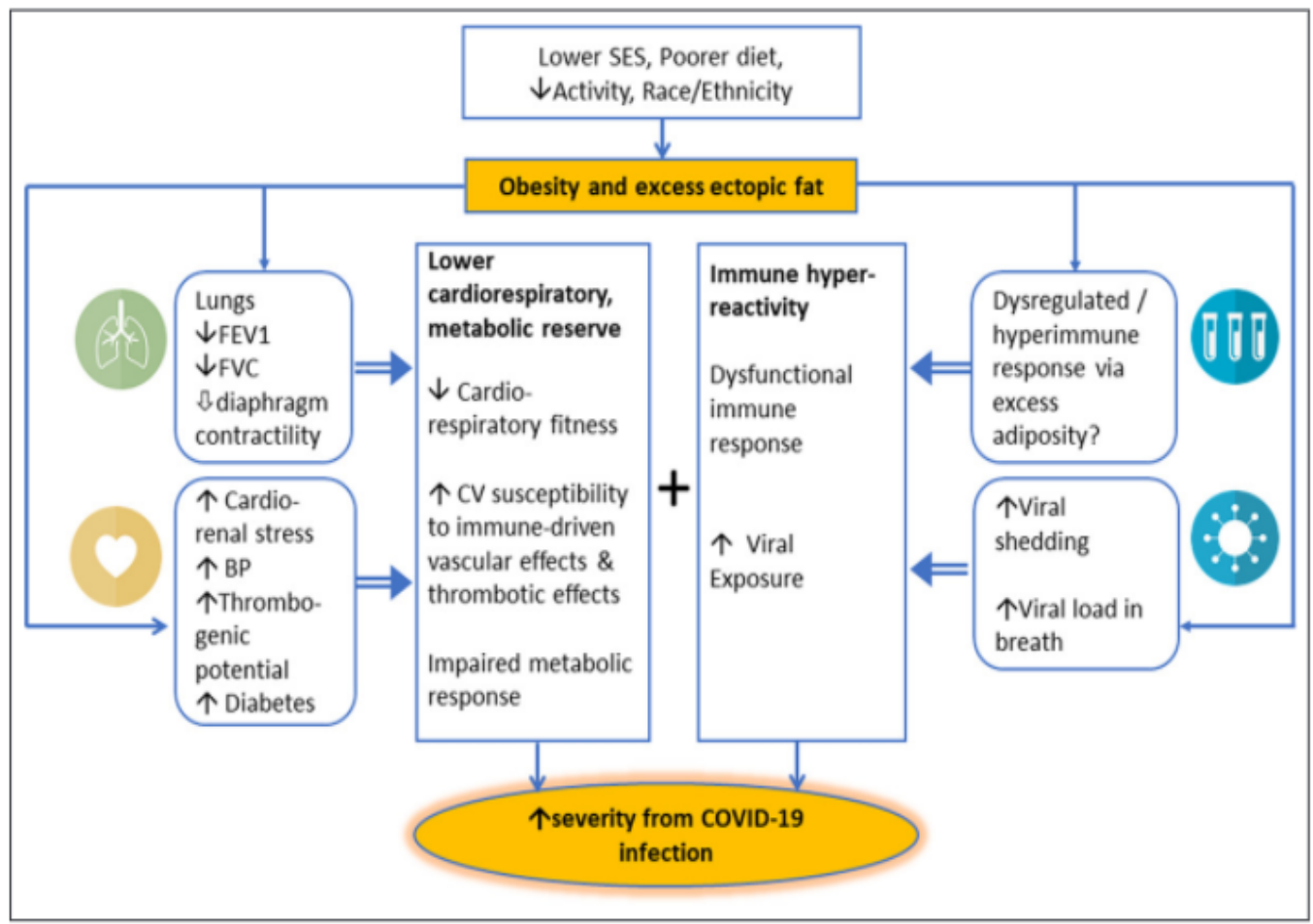

Hình 3. Béo phì hay có quá nhiều mỡ làm tăng nguy cơ nhiễm COVID-19. Kể cả có bệnh nền liên quan đến béo phì như như tim mạch, hô hấp, chuyển hóa, huyết khối

BP: blood pressure; CV, cardiovascular; FEV1: Forced expiratory volume; FVC: forced vital

Điều trị và dự phòng. capacity; and SES, socioeconomic status.

Có hai vấn đề: Điều trị béo phì và bệnh nhiễm COVID-19. Nếu béo phì có hại cho tiến triển COVID-19, những điều trị gần đây nhắm mục tiêu vào mô mõ̃, do mô mỡ đóng vai trò hoạt hóa miễn dịch mạnh và gây viêm, tăng cytokine và đặc biệt IL-6 hay còn cả hệ thống phức hợp.

Có vài $\mathrm{NC}$ đã tường trình về Tocilizumab, nhưng không đặc hiệu ở người béo phì. Gần đây nhóm chuyên gia «the Diabetes Surgery Summit consensus conference series » đã công bố một loạt khuyến cáo chọn lựa $\mathrm{BN}$ béo phì để phẩu thuật giảm béo và tối ưu hóa theo dõi trong thời gian bị dịch COVID-19.

Về dự phòng béo phì, thì quan trọng là tiết thực lành mạnh, tập luyện thể dục đều đăn.
Khi người béo phì bị nhiễm hay nghi ngờ nhiễm COVID-19, ở giai đoạn sớm và có ít triệu chứng của nhiễm bệnh, cần cho nhập viện gấp, theo dõi kỷ tránh diễn tiến xấu, ít nhất cũng hạn chế nguy cơ bất lợi.

\section{KẾT LUẬN}

Hiện nay, nhân loại phải đương đầu với hai vụ dịch, đó là COVID-19 và béo phì. Những người có $B M I>30 \mathrm{~kg} / \mathrm{m}^{2}$ là yếu tố nguy cơ dễ gây nhiễm COVID-19 trầm trọng, đó là hội chứng suy hô hấp cấp cần phải đặt nội khí quản và thông khí.

Đã có nhiều cơ chế giải thích về sự tiến triển nhanh của bệnh. Từ đó tăng cường phương cách phòng ngừa và chữa trị để tránh 
diễn tiến xấu của bênh, kéo dài thời gian nằm viện, thậm chí tử vong.

\section{TÀI LIỆU THAM KHẢO}

1. André J. et all (2020). Obésité et risque de COVID-19 sévère. Rev Med Suisse 2020; 16: 1115-9

2. Buscemi S, Buscemi C, Batsis JA. There is a relationship between obesity and COVID-19 but more information is needed. Obesity (Silver Spring). 2020 May 12. 3. Demetrios Petrakis, Denisa Margină. Obesity - a risk factor for increased COVID-19 prevalence, severity and lethality (Review). Received April 6, 2020; Accepted May 5, 2020

3. Yi HUANG, L.U. Yao, Yan-Mei HUANG. Obesity in patients with COVID-19: a systematic review and meta-analysis. Journal Pre-proof. 2020

4. Kelvin Ka et all. NLRP3 Inflammasome Activation in Adipose Tissues and Its Implications on Metabolic Diseases. Mol. Sci. 2020, 21, 4184.

5. Kissling S, Pruijm M. Vue sur le COVID-19 depuis la néphrologie. Rev Med Suisse 2020;16:842-4.

6. Lighter J, Phillips M, Hochman S, et al. Obesity in patients younger than 60 years is a risk factor for Covid-19 hospital admission. Clin Infect Dis. 2020 Apr 9.

7. Luca Pericoa, Ariela Benignia, Giuseppe Remuzzia.Should COVID-19 Concern Nephrologists? Why and to What Extent? The Emerging Impasse of Angiotensin Blockade. Nephron 2020;144:213-221

8. Naveed Sattar (2020). Obesity Is a Risk Factor for Severe COVID-19 Infection
Multiple Potential Mechanisms. Circulation. Volume 142, Issue 1, 7 July 2020, Pages 4-6

9. Petrilli CM, Jones SA, Yang J, et al. Factors associated with hospitalisation and critical illness among 4,103 patients with Covid-19 disease in New York city.

10. Richardson $S$, Hirsch $S$, Narasimhan $M$ et al. Presenting Characteristics, Comorbidities, and Outcomes Among 5700 Patients Hospitalized With COVID19 in the New York City Area.

11. Ryan PM, Caplice NM. Is adipose tissue a reservoir for viral spread, immune activation and cytokine amplification in COVID-19. Obesity. 2020 Apr 21.

12. Sattar N., McInnes IB, McMurray JJV. Obesity a risk factor for severe COVID19 infection: multiple potential mechanisms. Circulation. 2020 Apr 22.

13. Simonnet A, Chetboun M, Poissy J, et al. High prevalence of obesity in severe acute respiratory syndrome coronavirus-2 (SARS$\mathrm{CoV}-2)$ requiring invasive mechanical ventilation. Obesity, 2020 Apr 9.

14. Zhao L. Obesity accompanying COVID19: the role of epicardial fat. Obesity Obesity| VOLUME 28 | NUMBER 8 | AUGUST 2020

15. Zheng KI, Gao F, Wang XB, et al. Obesity as a risk factor for greater severity of COVID-19 in patients with metabolic associated fatty liver disease. Metabolism 2020; Apr 19;108:154244.

16. Réponses rapides dans le cadre du COVID-19 - Pathologies chroniques et risques nutritionnels en ambulatoire. Validée par le Collège le 16 avril 2020. 